\title{
The Application of Silica-Based Aerogel Board on the Fire Resistance and Thermal Insulation Performance Enhancement of Existing External Wall System Retrofit
}

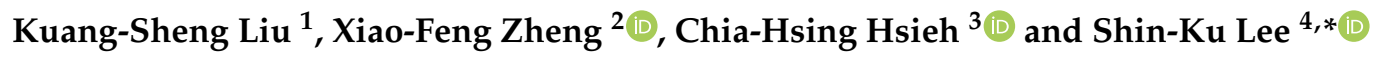 \\ 1 Department of Interior Design, TungFang Design University, Kaohsiung City 829003, Taiwan; \\ kliu1219@yahoo.com.tw \\ 2 School of Built Environment, Engineering and Computing, Leeds Beckett University, Leeds LS1 3HE, UK; \\ k.zheng@leedsbeckett.ac.uk \\ 3 Green Energy and Environment Research Laboratories, Industrial Technology Research Institute, \\ Hsinchu 310401, Taiwan; ChiaHsingHsieh@itri.org.tw \\ 4 Research Center for Energy Technology and Strategy, National Cheng-Kung University, \\ Tainan 701401, Taiwan \\ * Correspondence: sklee1015@gmail.com
}

check for

updates

Citation: Liu, K.-S.; Zheng, X.-F.; Hsieh, C.-H.; Lee, S.-K. The

Application of Silica-Based Aerogel

Board on the Fire Resistance and

Thermal Insulation Performance Enhancement of Existing External Wall System Retrofit. Energies 2021, 14, 4518. https://doi.org/10.3390/ en14154518

Academic Editor: Elena Cerro-Prada

Received: 8 June 2021

Accepted: 19 July 2021

Published: 26 July 2021

Publisher's Note: MDPI stays neutral with regard to jurisdictional claims in published maps and institutional affiliations.

Copyright: (C) 2021 by the authors. Licensee MDPI, Basel, Switzerland. This article is an open access article distributed under the terms and conditions of the Creative Commons Attribution (CC BY) license (https:/ / creativecommons.org/licenses/by/ $4.0 /)$.

\begin{abstract}
Due to the need of good thermal performance, external wall insulation (EWI) is usually made of materials that are not fire resistant and sometimes flammable. That restricts its application to a particular circumstance such as limited building height. Hence, a material with good thermal insulation and fire resistance performance would allow EWI to be more widely applied. This paper introduces a novel material: a silica-based aerogel porous board, which differs itself from mainstream products available in the market because of its outstanding properties, such as low density, high surface area, low thermal conductivity and superhydrophobicity. Herein, its thermal insulation and fire-resistant performance were tested and compared with commercial products. The cone calorimeter analysis results indicated that the aerogel porous board could improve the fire resistance performance. Moreover, the evaluation of thermal insulation performance suggested that the application of an aerogel porous board on the external stone wall of existing buildings can decrease the U-value by $60 \%$. Through the detailed insight into the case-study, it is quite clear that the carbon impact of building stock could be greatly reduced by means of a coherent set of building envelope retrofitting actions based on this innovative heat insulation material, without compromising the fire safety.
\end{abstract}

Keywords: existing building; external wall insulation; fire resistance; energy efficiency; aerogel

\section{Introduction}

Building energy retrofitting has become increasingly important as the energy consumption in the building sector represents a significant proportion in the overall energy consumption [1-3]. Hence, reducing the energy consumption in the building sector is highly necessary to decarbonize the sector. Delivering new low energy buildings and improving the energy efficiency of existing building stock are equally important to achieving that goal. External wall insulation (EWI) plays a very important role in building the energyretrofitting process because it is able to reduce the building energy demand, improve the indoor acoustic environment and extend the life span of the buildings by cutting down the heat loss through building fabric, filtering incoming external noises and preventing the formation of condensation in the wall [4-6]. Hence, as a low-hanging fruit, the measures of installing EWI has always been taken in building industries to cut down the carbon emission and in some occasion to improve the aesthetic of the buildings.

Currently, applying the thermal barrier coating on the outer surface of the wall or roof is a common solution to enhance the heat insulation performance of a building in the regions with a subtropical or tropical climate $[5,7,8]$. Alternatively, thermal insulation 
materials can be installed in roofs or exterior walls [9]. The EWI with good thermal performance, when installed correctly, can significantly reduce the energy demand of the building. However, the EWI is commonly made of materials that are flammable and therefore poses a fire risk to the building. When a building with conventional EWI is on fire, there may be thus significant risks to the lives of occupants and property safety. Several fire accidents have occurred in buildings around the world [10-12]. A recent and well-known one is the fire that occurred in Grenfell tower in London, United Kingdom in 2017, which was caused by the overlooked fire resistance of the installed EWI. Thus, the building fire safety codes in many countries [13-15] request such materials used in the buildings must meet certain fire resistance standards by testing. Common thermal insulation materials include the polyurethane (PU) foam board, polystyrene (PS) board and mineral wool board, which however come with certain drawbacks in one way or another and therefore have limited applications $[9,16]$. For instance, mineral wool is a flame-retarded material, but the thermal conductivity of the mineral wool board is much higher than that of the PU or PS foam board. On the other hand, the PU or PS foam board is an excellent material for thermal insulation, it is highly combustible and therefore its application comes with a fire risk.

One key property of the EWI material that fundamentally determines its fire risk is the flammability. The flammability of PU materials presents a threat to both the fire integrity of such an EWI product and to human health and safety. Therefore, searching for an appropriate fire retardant or synthesizing an inherently non-flammable PU is a significant scientific challenge [17]. Over the past decades, many research works [18-20] have been done to develop diols or polyols containing phosphorus or halogen, as a means for introducing flame retardancy into the PU structure by chemical bonding. In addition, methods to improve flame retardancy of PUs by using additive type flame retardants, such as expandable graphite and melamine, or reactive type flame retardants, such as organophosphorus compounds, cyclotriphosphazenes, aziridinyl curing agents in aqueous polyurethane dispersions (PUDs), organoboron compounds and organosilicon compounds have also been developed. Incorporation of carbon nanotubes (CNTs) into PUs and the use of functionalized fullerenes in PUs are the emerging methods to obtain good thermal stability and flame retardancy. However, flame retardant PUs are combustible materials that prevent or delay flashover from the surface of combustibles; a flame retardant is not designed to prevent the material from ignition but to keep the flame spread rate to a minimum and prevent sustained burning [20].

Recently, many research results of aerogel application in building materials have been published [21,22]. Aerogel found by Kistler [23] is solid with a porous microstructure. The traditional aerogel's three-dimensional network structure is mainly composed of silicon dioxide, which accounts for more than $90 \%$ of the nanometer-sized holes in the total volume. Aerogels have a low thermal conductivity, high porosity, low density, high surface area, low refractive index and low dielectric constant. These features make aerogel more competitive in different applications such as heat insulation, sound insulation and fire resistance. Thus, some aerogel products, such as coatings [24], blankets [25], glasses [26] and cementitious composites $[27,28]$, have been developed due to the outstanding properties.

The weather in Taiwan features hot, wet summers and warm, dry winters due to Taiwan's subtropical climate and Pacific Ocean location. The maximum daily temperature difference is within $20^{\circ} \mathrm{C}$ [29]. Therefore, Taiwan's building regulations regarding energy-saving codes for the building envelope are less stringent than those in cold zone countries. For example, the U-value criteria for the exterior wall and roof are $3.5 \mathrm{~W} / \mathrm{m}^{2} \mathrm{~K}$ and $0.8 \mathrm{~W} / \mathrm{m}^{2} \mathrm{~K}$, respectively. It implies that as the Taiwanese government needs to meet the global 2050 carbon-neutrality target, future building energy efficiency regulations must enhance the thermal insulation performance of the building envelope. In addition, due to its unique geographical environment, Taiwan is often hit by natural hazards such as typhoons, torrential rains and earthquakes, so most of the building structures are RC structures with external tiles. However, with the increase in the lifespan of buildings and 
the interaction of external factors such as typhoons, earthquakes and dramatic temperature changes, problems such as falling and defects of tiles will affect the buildings' appearance and even endanger the safety of the people.

Cities in Taiwan are densely populated with 80 percent of the total population living in urban areas. Yet some 34,000 of the 86,000 buildings over 30 years old do not meet the latest building code and seismic resistance standards. In 2020, the Taiwan government launched a new statute for expediting the reconstruction of urban unsafe and old buildings to improve citizens' living environment and building safety in response to the potential climate change and disaster risk. It is a quite important issue to propose a building envelope retrofitting scheme for such existing buildings to meet the criteria of the latest building codes [30].

Extensive research and industrial practices related to building energy retrofitting have been carried out in countries with a large percentage of old housing stocks [31-36]. For instance, the large uptake of building energy technologies and policy have enabled many member states in Europe to carry out state-wide energy retrofitting to improve the overall building energy efficiency in the building sector with many lessons learnt and lots of relevant knowledge accumulated. However, buildings in Taiwan cannot follow the same paths identified in countries with cold or moderate climates to improve the energy efficiency due to its unique climate and building characteristics.

Based on the problems as mentioned above, developing an advanced dry-type EWI solution with good fire safety and thermal insulation performance is imminent.

In the study, we prepared the MTMS-based silica aerogel porous board via the emulsion method combined with ambient pressure drying (APD). In addition, a series of experiments have been conducted to examine the basic properties of the aerogel porous board and then compared the thermal and fire-resistant performance between the aerogel porous board and three kinds of typical insulation materials, including the rigid PU foam board, fire-retardant rigid PU foam board [37] and rigid PS foam board [38]. The final objective was to evaluate the energy efficiency of the aerogel porous board applied in the EWI system of a case study in Taiwan. By achieving these objectives, it was expected to reduce the operational energy consumption of either new or existing buildings without compromising the fire safety quality. Due to the integrated properties shown in this study, the as-formed aerogel porous board have demonstrated promising applications in delivering improved energy efficiency and fire safety in existing buildings.

\section{Materials and Methods}

\subsection{Preparation of the Aerogel Porous Board}

In this study, silica aerogel microspheres are prepared at two-step sol-gel synthesis, which is base-catalyzed condensation of methyltrimethoxysilane (MTMS) as the silica precursor [39]. The method for preparing the aerogel porous board includes the steps of: (a) adding a 50-70 vol.\% MTMS containing methyl groups and a $0.1-0.3$ vol.\% surfactant into water, mixing evenly and carrying out hydrolysis to get a mixed aqueous solution; (b) mixing the $12-16$ vol.\% of mixed aqueous solution with 5-6 vol.\% of $0.1-0.2 \mathrm{M}$ ammonium hydroxide $\left(\mathrm{NH}_{4} \mathrm{OH}\right)$ and a remaining percentage of an organic solvent according to the percentage by volume (vol.\%) and mixing by the magnetic stirrer until the solution obtained clear color in the hydrolysis reaction for emulsion polymerization to get a water-in-oil (w/o) lotion emulsion; (c) subsequently, the wet gels were shaped in a $10 \mathrm{~cm} \times 10 \mathrm{~cm} \times$ $1.5 \mathrm{~cm}$ steel mold at $150^{\circ} \mathrm{C}$ in an oven for $24 \mathrm{~h}$. The aerogel porous board was obtained by the ambient pressure drying (APD) method. Figure 1 shows the flow chart of the aerogel porous board manufacture via the sol-gel process. 

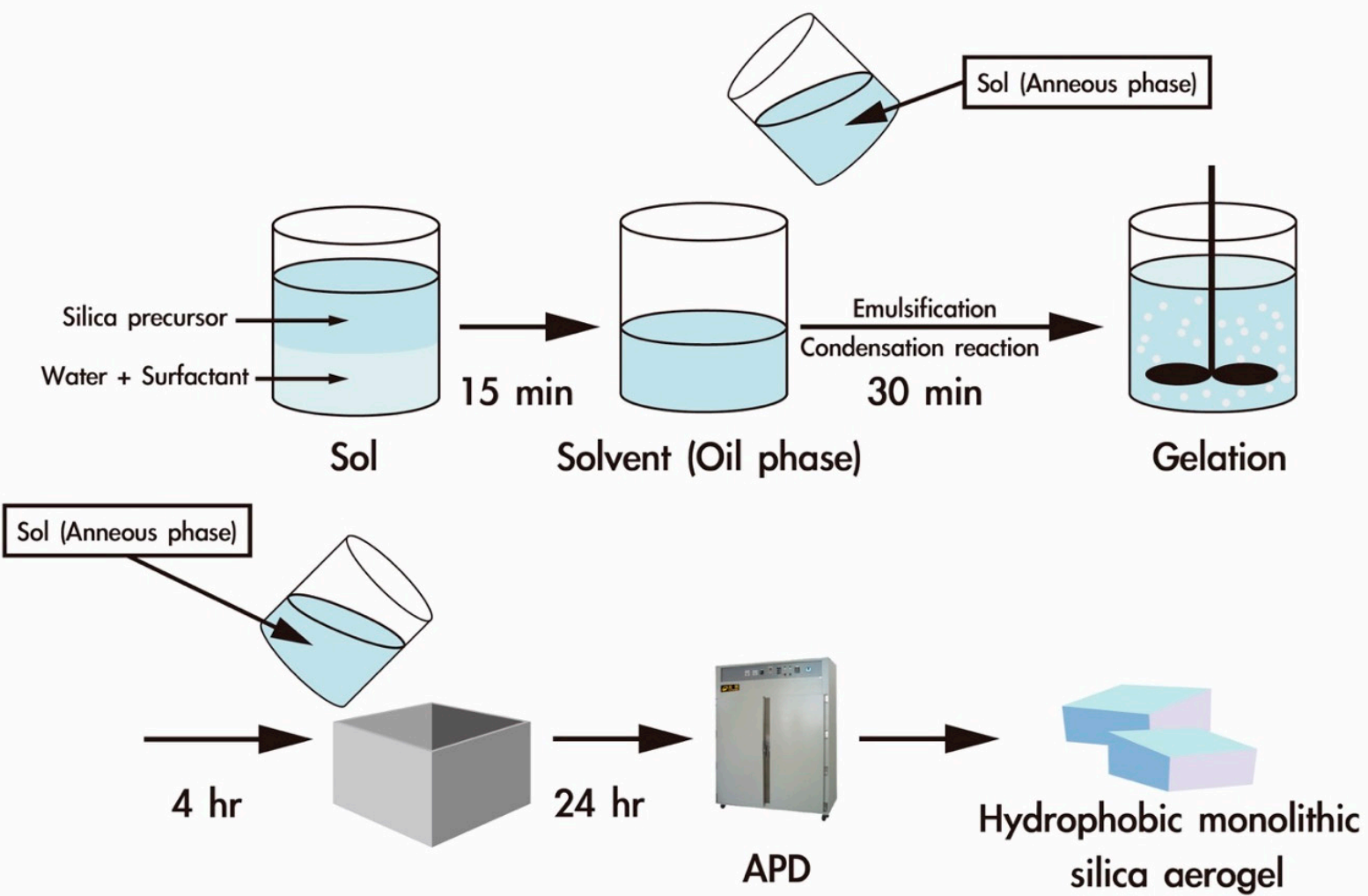

Figure 1. Schematic description of the formation of the aerogel porous board via the emulsion method combined with APD.

\subsection{Methods of Characterization}

The morphology of the aerogel was observed by scanning electron microscopy (SEM). The SEM images were recorded on a FE-SEM microscope JEOL JSM-7001 operated at an accelerating voltage of $15 \mathrm{keV}$. The specimen was mounted on a metal stub using a conductive carbon adhesive disc with a $25 \mathrm{~mm}$ diameter. The samples' surfaces were sputter-coated with $\mathrm{Pt}$ prior to analysis. The surface area (the measurement range of the minimum: $0.01 \mathrm{~m}^{2} / \mathrm{g}$ ) of samples was determined by a BET analysis from the amount of $\mathrm{N}_{2}$ gas adsorbed at various partial pressures $\left(0.01<\mathrm{P} / \mathrm{P}_{0}<1\right)$ (NOVA 1000e, Quantachrome Instruments, Boynton Beach, FL, USA). Preheating of samples was performed in a nitrogen flow for $3 \mathrm{~h}$ at $200{ }^{\circ} \mathrm{C}$ to remove all the volatile materials. Additionally, the specific surface areas were determined by using the BET equation with an accuracy of $\pm 10 \mathrm{~m}^{2} / \mathrm{g}$. The pore volume (at STP the measurement range of minimum: $0.0001 \mathrm{cc} / \mathrm{g}$ ) and pore size distributions (the measurement of range: $3.5-4000 \AA$ ) were measured using the $\mathrm{BJH}$ cumulative pore volume method. Fourier transform infrared spectroscopy (FTIR, Thermo iS50, Madison, WI, USA) with $4 \mathrm{~cm}^{-1}$ resolution and 40 scans for each curve was employed to investigate the molecular structure of the aerogel powder. The aerogel powder was mixed in the potassium bromide $(\mathrm{KBr})$ powder matrix and then placed this in the sample cup. To determine the porosity, bulk density and contact angle, the mercury porosimeter (AutoPore IV 9520, Micromeritics) and contact angle meter (CAM-121, Creating Nano) were used.

The thermal conductivity of the aerogel particle and aerogel porous board at $25{ }^{\circ} \mathrm{C}$ ambient temperature were studied using a thermal conductivity analyzer (TCI-3-A, TCi) in accordance with ASTM D7984 [40]. This device employs the patented modified transient plane source (MTPS) technique, which is the only instrument engineered for evaluating the thermal conductivity of powder without sample preparation. Finally, the fire resistance of the commercial external wall insulation materials and aerogel porous board were analyzed by the cone calorimeter method in accordance with CNS 14705-1-2013 [41], respectively. The cone calorimeter method is commonly used to examine the reactions of materials in a 
fire by simulating different fire scenarios (ignition period radiant heat: $15 \mathrm{~kW} / \mathrm{m}^{2}$; growth period radiant heat: $30 \mathrm{~kW} / \mathrm{m}^{2}$; growth period radiant heat: $50 \mathrm{~kW} / \mathrm{m}^{2}$ ). The specimens with a surface area of $88.4 \mathrm{~cm}^{2}$ and $1.5 \mathrm{~cm}$ thick were heated by an incident radiant heat flux of $50.0 \mathrm{~kW} / \mathrm{m}^{2}$ (about $737^{\circ} \mathrm{C}$ ) in a horizontal orientation. The test duration was $20 \mathrm{~min}$. The size of all specimens for thermal conductivity and fire resistance testing were $10 \mathrm{~cm}$ in length, $10 \mathrm{~cm}$ in width and $1.5 \mathrm{~cm}$ in height.

In order to evaluate the applicability of aerogel porous board under high humidity conditions. The water absorption of aerogel porous board was measured in accordance with ASTM D570-98 [42]. For the water absorption test, the aerogel porous board was dried in a chamber for a specified time and at temperature and then the aerogel porous board was weighed. The aerogel porous board was then submerged in water at $23{ }^{\circ} \mathrm{C}$ for $24 \mathrm{~h}$. The specimen was removed, patted dry with a lint free cloth and weighed. Water absorption of the aerogel porous board can be calculated by $\left(\mathrm{m}_{1}-\mathrm{m}_{0}\right) / \mathrm{A} \times 100 \%$.

All these tests allowed evaluating the microstructural and physical performance, with the sample/test pairing summarized in Table 1.

Table 1. Tests conducted for each sample.

\begin{tabular}{|c|c|c|c|c|c|c|c|c|}
\hline \multirow{2}{*}{ Material } & \multicolumn{5}{|c|}{ Microstructural } & \multicolumn{3}{|c|}{ Physical } \\
\hline & SEM & BET & BD & CA & FTIR & $\lambda$ & FR & WA \\
\hline Aerogel porous & $X$ & $x$ & $x$ & $x$ & $x$ & $x$ & $x$ & $x$ \\
\hline board & P1 & P2 & $\mathrm{P} 1$ & $\mathrm{R} 1$ & P2 & R1 & R1 & R1 \\
\hline Aerogel particle & $\begin{array}{c}X \\
P 1\end{array}$ & $\begin{array}{l}X \\
P 2\end{array}$ & $\begin{array}{c}X \\
P 1\end{array}$ & $\begin{array}{l}X \\
P 1\end{array}$ & - & $\begin{array}{c}X \\
\text { R1 }\end{array}$ & - & - \\
\hline PU & - & - & - & - & - & $\begin{array}{c}X \\
\text { R1 }\end{array}$ & $\begin{array}{c}X \\
\mathrm{R} 1\end{array}$ & - \\
\hline PS & - & - & - & - & - & $\begin{array}{c}X \\
\mathrm{R} 1\end{array}$ & $\begin{array}{c}\mathrm{X} \\
\mathrm{R} 1\end{array}$ & - \\
\hline $\begin{array}{c}\text { Flame-retardant } \\
\text { PU }\end{array}$ & - & - & - & - & - & $\begin{array}{c}X \\
\text { R1 }\end{array}$ & $\begin{array}{c}X \\
\mathrm{R} 1\end{array}$ & - \\
\hline
\end{tabular}

Caption: SEM-scanning electron microscope; BET- $\mathrm{N}_{2}$ adsorption-desorption isotherms; BD—dry bulk density CA-contact angle; FTIR-Fourier-transform infrared spectroscopy; $\lambda$-thermal conductivity; FR-cone calorimeter; WA —water absorption; Specimen size: P1—10 mg powder; P2— 0.1 g powder; P3 $-5 \mathrm{~g}$ powder; R1— $10 \mathrm{~cm} \times$ $10 \mathrm{~cm} \times 1.5 \mathrm{~cm}$.

\section{Results and Discussion}

\subsection{Characterization of the Aerogel Porous Board}

Figure 2 shows the images of the aerogel porous board at various magnifications. As shown in Figure 2a, the aerogel porous board is white and opaque. The bulk density of the aerogel porous board is $0.0301 \mathrm{~g} / \mathrm{cm}^{3}$. A SEM image shown in Figure $2 \mathrm{~b}$ clearly illustrates the presence of the porous network structure with pores of different sizes.

The FTIR characterization results of the aerogel porous board is shown in Figure 3. The peaks centered at 3445, 1632 and $952 \mathrm{~cm}^{-1}$ are attributed to the $\mathrm{O}-\mathrm{H}$ stretching band of hydrogen-bonded water, respectively. The peak at 1050 and $758 \mathrm{~cm}^{-1}$ for Si-O-Si stretching vibration corresponds to the structure of the silica network. The peaks at $2963 \mathrm{~cm}^{-1}$, $1380 \mathrm{~cm}^{-1}$ and $848 \mathrm{~cm}^{-1}$ can be attributed to the absorption of $\mathrm{C}-\mathrm{H}$. The presence of $\mathrm{Si}-\mathrm{CH}_{3}$ functionalities is confirmed by the Si-C mode at $1260 \mathrm{~cm}^{-1}$. Furthermore, the aerogel porous board synthesized from MTMS is inherently hydrophobic in this study. Figure 4 indicated that the aerogel porous board is hydrophobic with a contact angle as high as $145^{\circ}$, thus, water can form droplets on the surface of the aerogel porous board. In addition, the water absorption of aerogel porous board was $0.186 \mathrm{~g} / 100 \mathrm{~cm}^{2}$. 


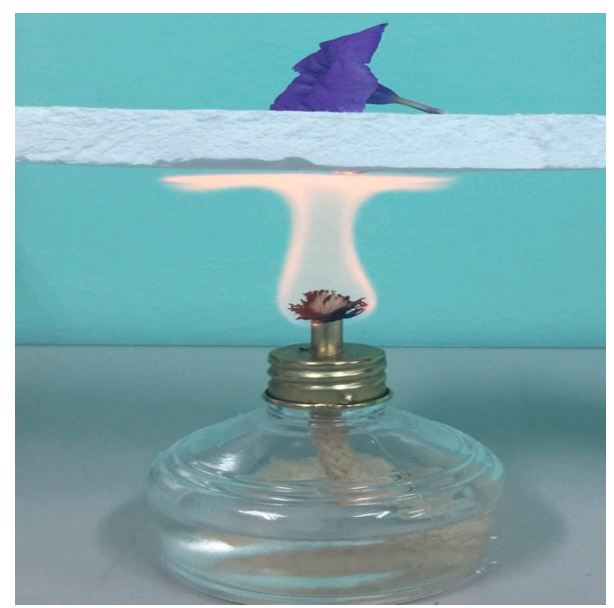

(a)

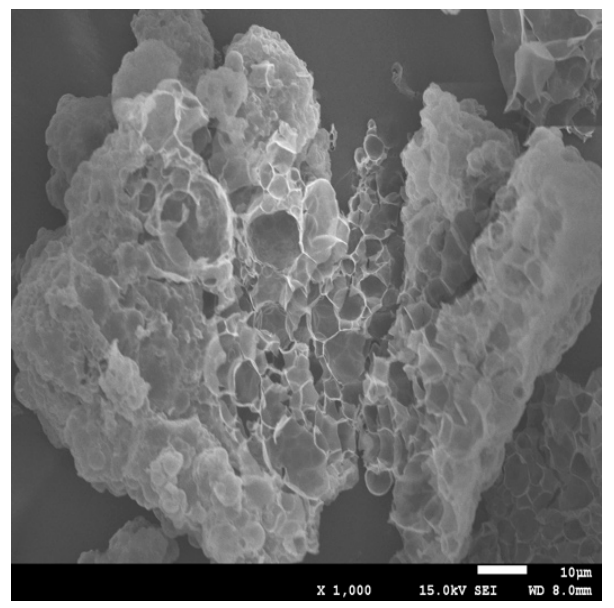

(b)

Figure 2. The appearance (a) and SEM image (b) of the aerogel porous board.

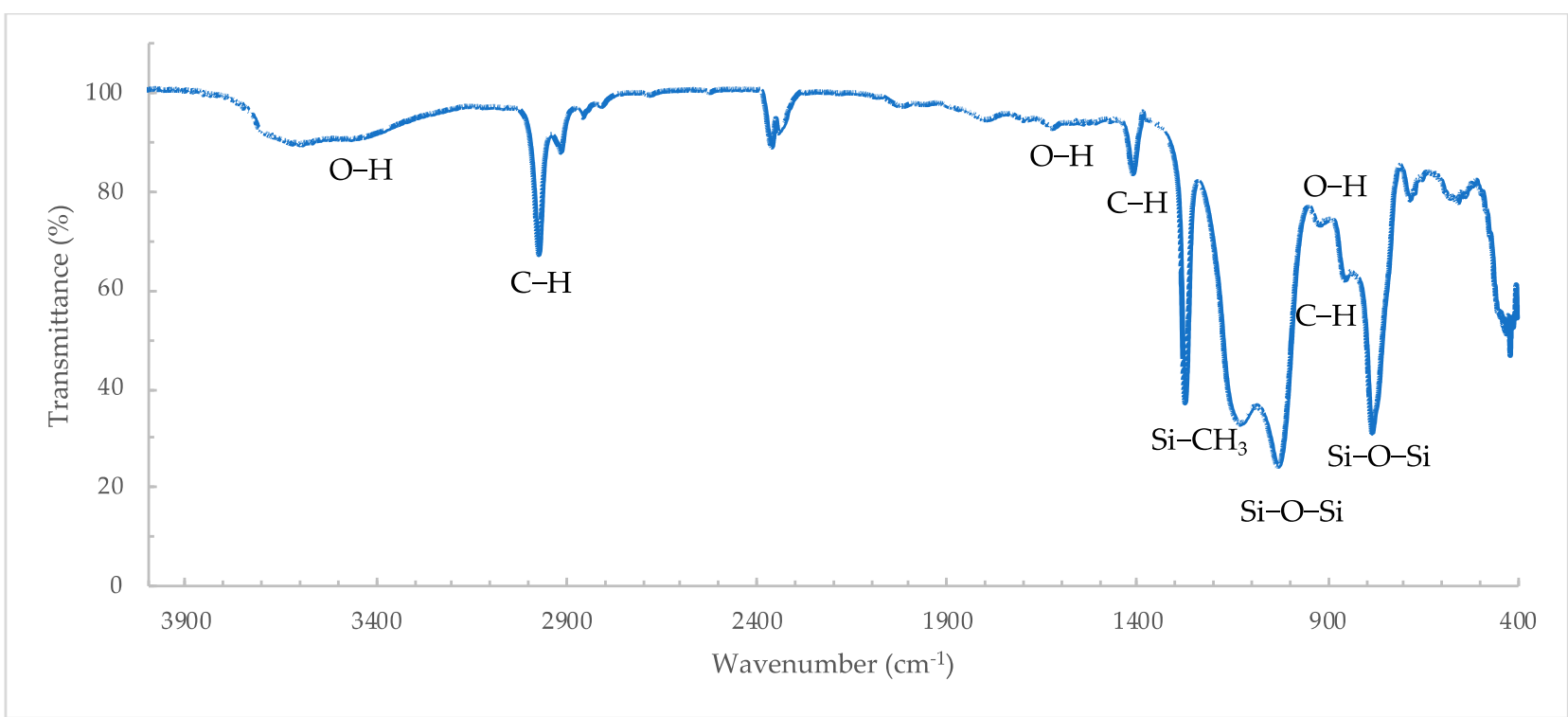

Figure 3. FTIR spectrum of the aerogel porous board.

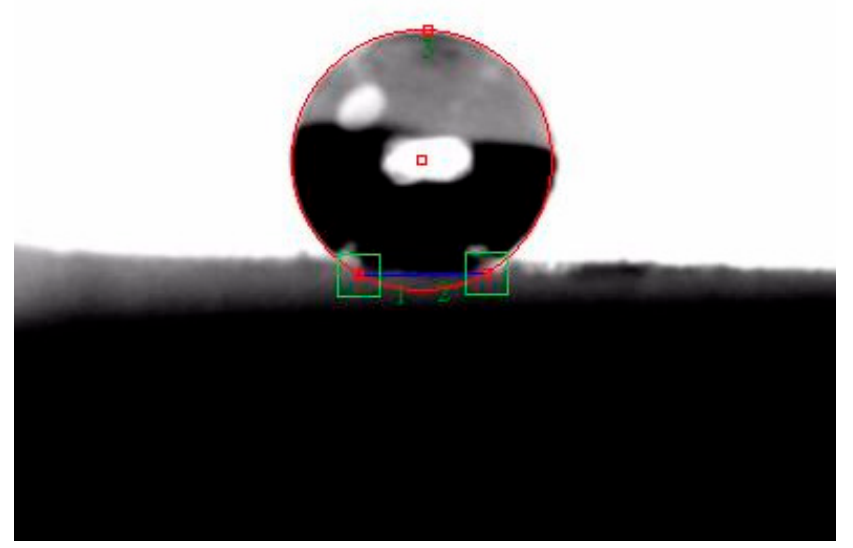

Figure 4. The water contact angle on the surface of aerogel porous board. 
Figure 5 shows the nitrogen adsorption-desorption isotherm and pore size distribution (PSD) of the aerogel porous board, which are obtained by using the standard BET and $\mathrm{BJH}$ cumulative pore volume method, respectively. The aerogel porous board exhibited the type-IV adsorption isotherm according to the IUPAC classification [43], which is a characteristic feature of the mesoporous material. The average pore size was found to be approximately $2.47 \mathrm{~nm}$ in Figure 2b. The aerogel porous board prepared in this work had a specific surface area as high as $547 \mathrm{~m}^{2} / \mathrm{g}$.

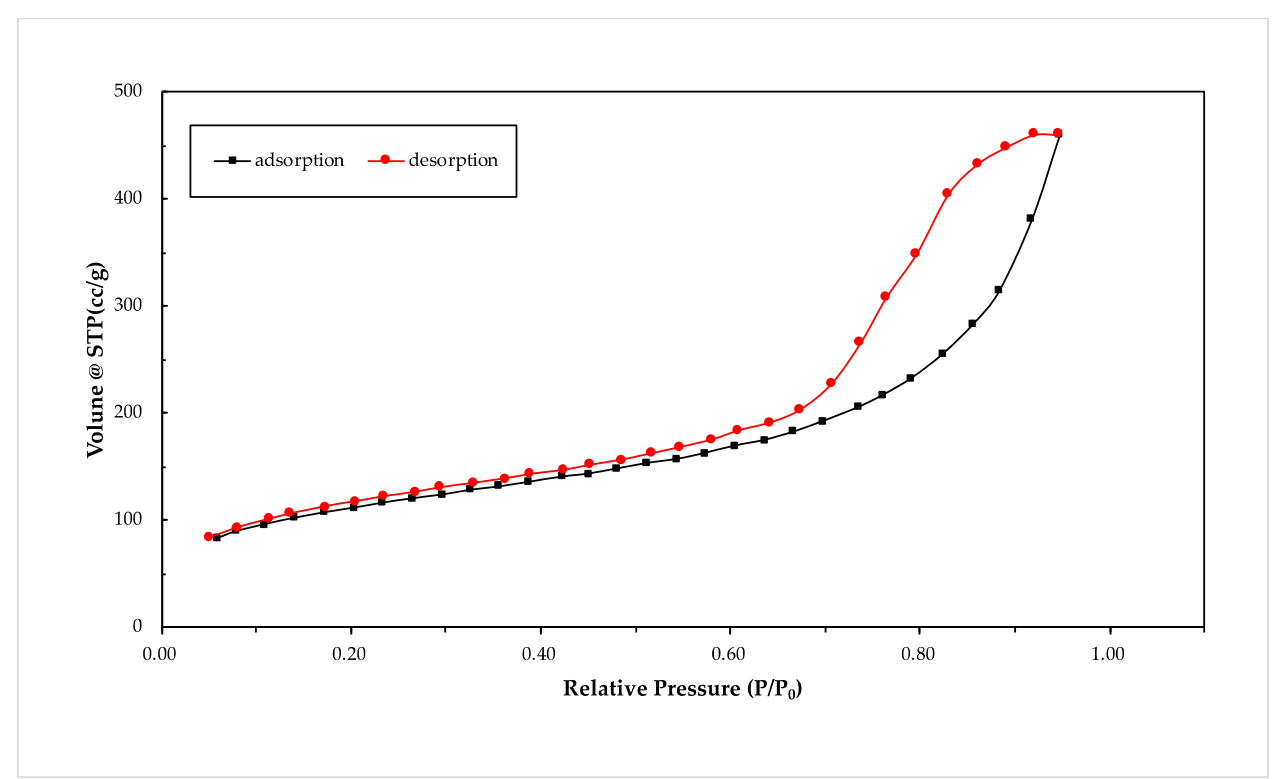

(a)

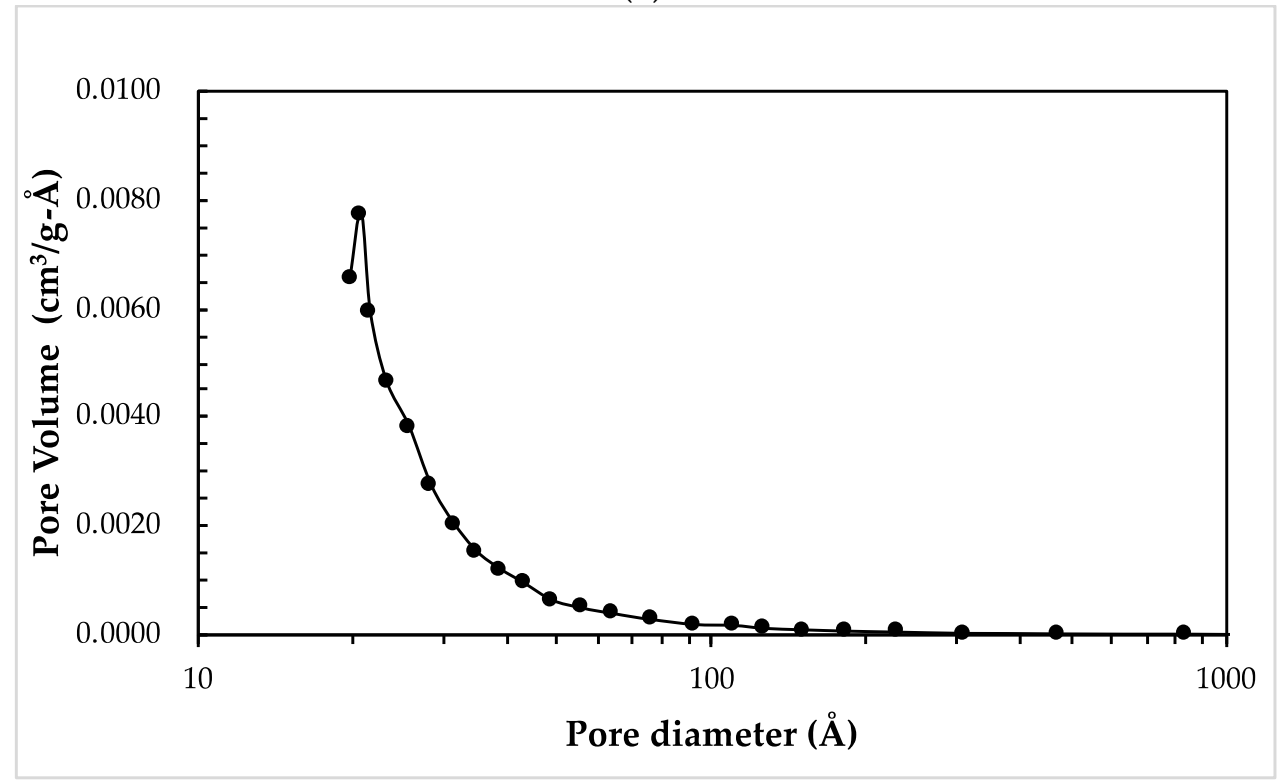

(b)

Figure 5. (a) Nitrogen adsorption-desorption isotherms and (b) pore size distribution curve of the aerogel porous board.

The characteristics of the aerogel porous board compared with the Cabot P300 aerogel particle are summarized in Table 2. Considering that the required aerogel porous board must have low density and high porosity, it can be concluded that the performances of the aerogel porous board prepared via the emulsion method combined with APD are similar to that of the aerogel particle. 
Table 2. Comparison of the characteristics between the aerogel porous board and aerogel particle.

\begin{tabular}{ccc}
\hline Property & $\begin{array}{c}\text { Aerogel Porous } \\
\text { Board }\end{array}$ & $\begin{array}{c}\text { Aerogel Particle } \\
\text { (Cabot P300) }\end{array}$ \\
\hline Specific surface area $\left(\mathrm{m}^{2} / \mathrm{g}\right)$ & 547 & $600-800$ \\
Porosity & $92 \%$ & $90 \%$ \\
Bulk density $\left(\mathrm{g} / \mathrm{cm}^{3}\right)$ & 0.035 & 0.06 \\
Pore diameter $(\mathrm{nm})$ & 2.47 & 20 \\
Thermal conductivity $(\mathrm{W} / \mathrm{mK})$ & 0.033 & 0.026 \\
Contact angel & $145^{\circ}$ & $151^{\circ}$ \\
\hline
\end{tabular}

\subsection{Thermal Conductivity}

Thermal conductivity is the important indicator for evaluating the thermal performance of a material under constant conditions. The comparison of thermal conductivity between the aerogel porous board, silica aerogel particle (Cabot, P300) and several thermal insulation materials used commercially for building insulation, such as the rigid PU and PS foam board, are made in Figure 6. The thermal conductivity of each material was measured with three samples. As shown in Figure 6, the mean thermal conductivity of the aerogel porous board at $25^{\circ} \mathrm{C}$ ambient temperature was $0.033 \mathrm{~W} / \mathrm{mK}$ with a standard deviation of $0.00085 \mathrm{~W} / \mathrm{mK}$. At ambient temperature and pressure conditions, the trapped air within the mesoporous aerogel is a major contributor to its low thermal conductivity. The thermal conductivity $(0.033 \mathrm{~W} / \mathrm{mK})$ of the proposed aerogel porous board was slightly lower than those of monolithic silica aerogels prepared with different surface modification procedures $(0.036-0.0417 \mathrm{~W} / \mathrm{mK})$ [44]. However, $1 \mathrm{wt} \%$ of glass fiber added in the aerogel porous board for increasing its mechanical strength led to the thermal conductivity of the aerogel porous board higher than that of the commercially available aerogel particle $(0.026 \mathrm{~W} / \mathrm{mK}$ with a standard deviation of $0.002 \mathrm{~W} / \mathrm{mK}$ ).

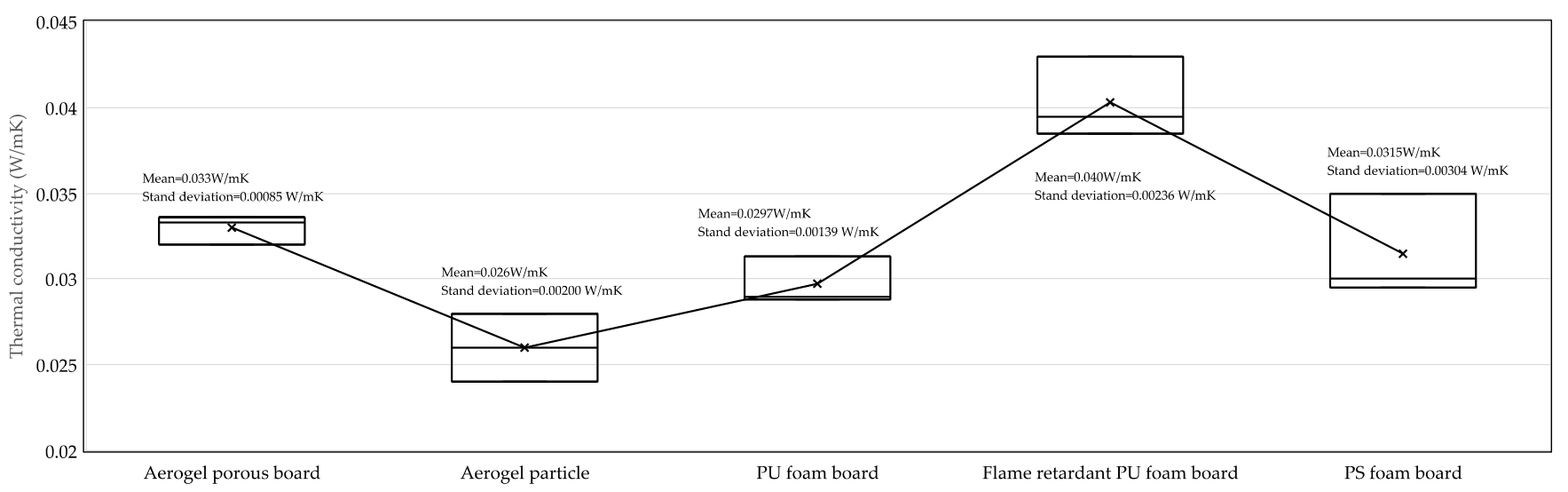

Figure 6. Comparison of the thermal insulation property between the aerogel porous board and commercially available materials.

The rigid PU foam board had the lowest thermal conductivity $(0.0297 \mathrm{~W} / \mathrm{mK}$ with a standard deviation of $0.0014 \mathrm{~W} / \mathrm{mK}$ ) among the three types of foam board. The thermal conductivity of the foam board was mainly density-dependent; the lower density foam board shows comparatively lower thermal conductivity than the higher density ones. The expandable graphite was added as an intumescent flame retardant into PUs, the density of the flame-retardant rigid PU foam board increased from 70 to $80 \mathrm{~kg} / \mathrm{m}^{3}$. Thus, the thermal conductivity of the flame-retardant rigid PU foam board $(0.040 \mathrm{~W} / \mathrm{mK}$ with a standard deviation of $0.0024 \mathrm{~W} / \mathrm{mK}$ ) was $35 \%$ higher than that of the rigid PU foam board. Polystyrene foams (PSs) are also now widely used as thermal insulators in building and construction. The thermal conductivity of the PS board mainly depends on the blowing 
agent and the concentration of IR-attenuators. The measured thermal conductivity of the commercial PS board was in the range of $0.0295-0.035 \mathrm{~W} / \mathrm{mK}$.

Compared with the other typical foam boards, the thermal conductivity of the aerogel porous board was slightly higher than that of the other ones, but the U values of the EWI system with anyone should be similar to each other. In addition, the density of the aerogel porous board was the lightest of the three. These results imply that the aerogel porous board prepared via the emulsion method combined with APD has potential application prospects in building thermal insulation.

\subsection{Fire Resistance}

It is observed from Figure 7 and Table 3 that the rigid PU foam board burned very fast after ignition, the pk-HRR value of the rigid PU foam board was $388.3 \mathrm{~kW} / \mathrm{m}^{2}$ and the whole combustion time of the rigid PU foam board was $182 \mathrm{~s}$. The flame-retardant rigid PU foam board due to the addition of EG could depress the HRR value to $83.25 \mathrm{~kW} / \mathrm{m}^{2}$, which was $78.6 \%$ lower than that of the rigid PU foam board. The HRR curve of the flameretardant rigid PU foam board is typical of an intumescent system, exhibiting two peaks. The first peak is related to the fast formation of an expanded protective layer structure on the surface of PU that prevents heat penetration, while the second peak is due to the destruction of the intumescent structure and the formation of a carbonaceous residue [45]. The effective heat of combustion (EHC) also revealed the burning degree of volatile gases in the gas phase during combustion. The av-EHC value of the flame-retardant rigid PU foam board was $16.12 \mathrm{MJ} / \mathrm{kg}$, which decreased by $25.1 \%$ compared to that of the rigid PU foam board. The HRR curve of the aerogel porous board in Figure 8 indicates that the HRR values increased rapidly to the peak and then declined slowly to near 0 . It is generally believed that heat generated when the organic materials, such as n-hexane, trapped in aerogel were evaporated. The HRR, pk-HRR and THR values show a significant reduction compared with the rest of building insulation materials. It is worth noting that the THR value of the aerogel porous board was $3.0 \mathrm{MJ} / \mathrm{m}^{2}$, a drop of $77.4 \%$ compared with the flame retardant rigid PU foam board $\left(13.3 \mathrm{MJ} / \mathrm{m}^{2}\right)$. These results indicated that the aerogel porous board can dramatically inhibit the combustion intensity and restrict the heat release during combustion. It could reach the non-flammable class 1 in accordance with CNS 14705-1-2013.

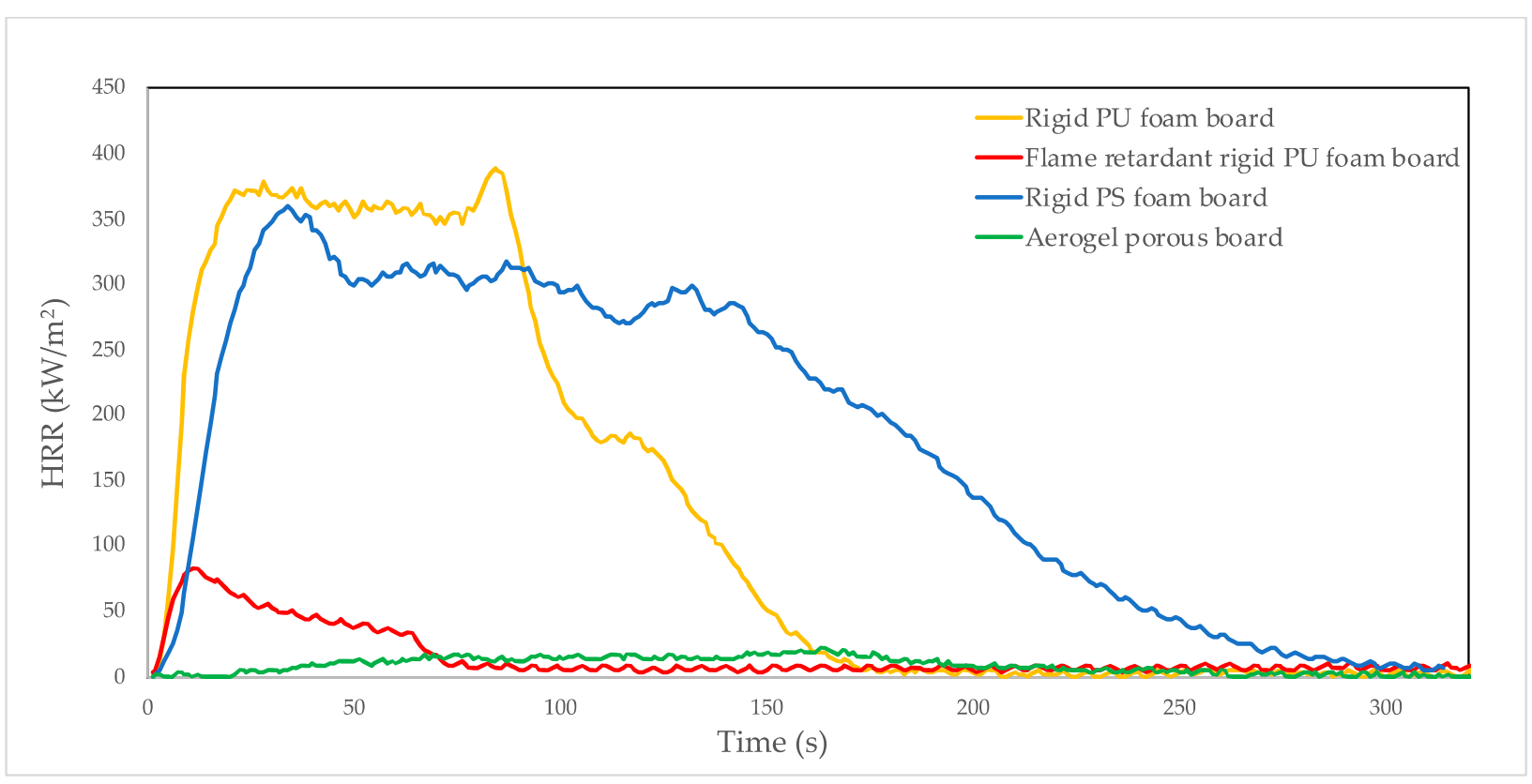

Figure 7. HRR curves of different EWIs under the $50 \mathrm{~kW} / \mathrm{m}^{2}$ radiant heat flux. 
Table 3. Combustion parameters obtained from the cone calorimeter.

\begin{tabular}{|c|c|c|c|c|c|}
\hline Samples & $\begin{array}{c}\text { Time to } \\
\text { Ignition (s) }\end{array}$ & $\begin{array}{c}\text { Flameout } \\
\text { (s) }\end{array}$ & $\begin{array}{l}\text { pk-HRR } \\
\left(\mathrm{kW} / \mathrm{m}^{2}\right)\end{array}$ & $\begin{array}{c}\text { THR } \\
\left(\mathrm{MJ} / \mathrm{m}^{2}\right)\end{array}$ & $\begin{array}{l}\text { av-EHC } \\
\text { (MJ/kg) }\end{array}$ \\
\hline Rigid PU foam board & 7 & 182 & 388.30 & 44.3 & 21.52 \\
\hline $\begin{array}{l}\text { Flame-retardant rigid } \\
\text { PU foam board }\end{array}$ & 2 & 61 & 83.25 & 13.3 & 16.12 \\
\hline Rigid PS foam board & 2 & 279 & 361.09 & 56.8 & 35.74 \\
\hline Aerogel porous board & 0 & 0 & 22.11 & 3.0 & 16.59 \\
\hline
\end{tabular}

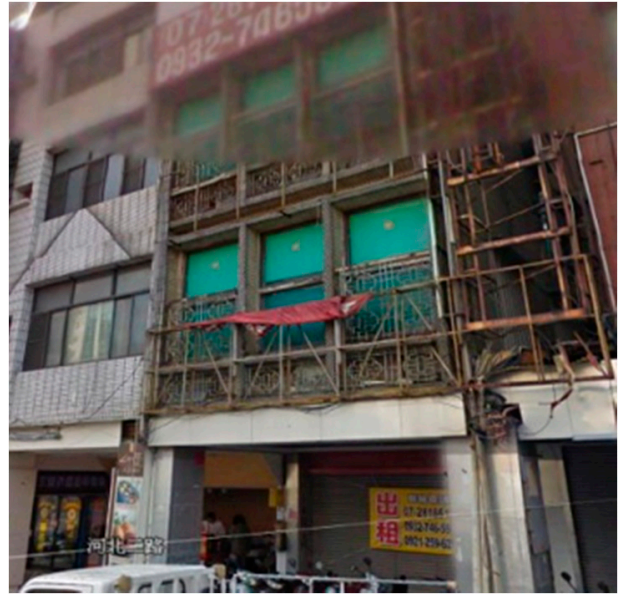

(a)

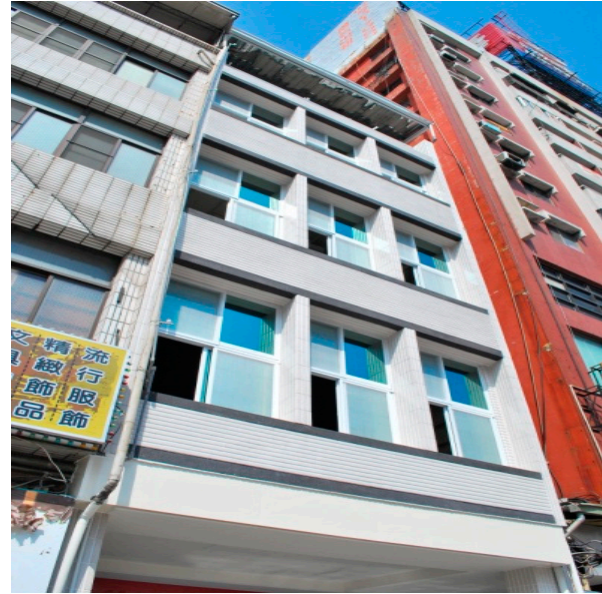

(b)

Figure 8. Street view of the case study building before (a) and after (b) retrofit.

\subsection{Thermal Transmittance}

In order to evaluate the impact of the application of the aerogel porous board on the thermal insulation performance of the external wall, the thermal transmittance, also known as the U-value, was used in this study. The thermal transmittance calculated by the formula in accordance with ISO 10292 [46] is shown in Equation (1):

$$
\mathrm{U}=\frac{1}{\frac{1}{\mathrm{~h}_{\mathrm{e}}}+\sum \frac{\mathrm{d}_{\mathrm{i}}}{\lambda_{\mathrm{i}}}+\frac{1}{\mathrm{~h}_{\mathrm{i}}}}
$$

where $h_{e}\left(W / m^{2} K\right)$ and $h_{i}\left(W / m^{2} K\right)$ are the external and internal heat transfer coefficients respectively. $\lambda_{i}(\mathrm{~W} / \mathrm{mK})$ and $\mathrm{d}_{\mathrm{i}}(\mathrm{m})$ are the thermal conductivity and thickness of each material.

The external heat transfer coefficient is a function of the wind speed, $v$, near the outdoor surface of the wall system given by the following approximate formula: $h_{e}=10.0+4.1 v$. The internal heat transfer coefficient was given by $h_{i}=3.9+6.3 \varepsilon$. The value $h_{e}$ and $h_{i}$ equal to 23 and $9 \mathrm{~W} / \mathrm{m}^{2} \mathrm{~K}$ were used in this study.

Table 4 lists the thermal transmittance of dry stone cladding with the aerogel porous board alongside two typical external wall types including $15 \mathrm{~cm}$ of RC external wall and dry stone cladding on the external wall. U-value rates in dry construction technologies were comparatively low when compared to traditional wall systems, such as reinforced concrete structure $\left(15 \mathrm{~cm}\right.$ thickness, $\left.3.495 \mathrm{~W} / \mathrm{m}^{2} \mathrm{~K}\right)$. The $\mathrm{U}$ value of the dry construction system for $2 \mathrm{~cm}$ stone cladding on the $15 \mathrm{~cm}$ RC wall contained in a gap of $8 \mathrm{~cm}$ could decrease to $2.413 \mathrm{~W} / \mathrm{m}^{2} \mathrm{~K}$. The utilization of dry construction with stone cladding on the external wall with an additional aerogel porous board unit demonstrated its capacity to reduce the U-value to as low as $1.394 \mathrm{~W} / \mathrm{m}^{2} \mathrm{~K}$, representing a promising assembly for insulating purposes when its overall thickness is not a restriction for building implementation. The thermal transmittance of this proposed dry construction wall system was already lower 
than the evaluation criterial $\left(1.8 \mathrm{~W} / \mathrm{m}^{2} \mathrm{~K}\right)$ of the green building materials rating system in Taiwan.

Table 4. The U value of the building wall system.

\begin{tabular}{|c|c|c|c|c|c|c|}
\hline $\begin{array}{c}\text { Wall } \\
\text { Assembly }\end{array}$ & Architectur & Details & $\begin{array}{l}\text { Thickness } \\
\text { dx (m) }\end{array}$ & $\begin{array}{c}\text { Thermal } \\
\text { Conductivity } \\
(\mathrm{W} / \mathrm{mK})\end{array}$ & $\begin{array}{l}\text { Thermal } \\
\text { Resistance } \\
\left(\mathrm{m}^{2} \mathrm{~K} / \mathrm{W}\right)\end{array}$ & $\begin{array}{l}\text { U Value } \\
\left(\mathrm{W} / \mathrm{m}^{2} \mathrm{~K}\right)\end{array}$ \\
\hline \multirow{6}{*}{$\begin{array}{l}15 \mathrm{~cm} \\
\text { RC WALL }\end{array}$} & & $\begin{array}{c}\text { External Heat } \\
\text { Transfer Coefficient }\end{array}$ & - & - & 0.0435 & \multirow{6}{*}{3.495} \\
\hline & & Tile & 0.010 & 1.3 & 0.0077 & \\
\hline & & Cement Mortar & 0.015 & 1.5 & 0.0100 & \\
\hline & & $\begin{array}{l}\text { Reinforced } \\
\text { Concrete }\end{array}$ & 0.150 & 1.4 & 0.1071 & \\
\hline & & Cement Mortar & 0.01 & 1.5 & 0.0067 & \\
\hline & & $\begin{array}{c}\text { Internal Heat } \\
\text { Transfer Coefficient }\end{array}$ & - & - & 0.1111 & \\
\hline \multirow{7}{*}{$\begin{array}{c}\text { dry stone } \\
\text { cladding on the } \\
\text { external wall }\end{array}$} & & $\begin{array}{c}\text { External Heat } \\
\text { Transfer Coefficient }\end{array}$ & - & - & 0.0435 & \multirow{7}{*}{2.413} \\
\hline & & Cladding & 0.020 & 0.4 & 2.5000 & \\
\hline & & Air Layer & - & - & 0.0500 & \\
\hline & & Cement Mortar & 0.015 & 1.5 & 0.0100 & \\
\hline & 8 & $\begin{array}{c}\text { Reinforced } \\
\text { Concrete }\end{array}$ & 0.150 & 1.4 & 0.1071 & \\
\hline & & Cement Mortar & 0.01 & 1.5 & 0.0067 & \\
\hline & $8 \quad t^{2} t$ & $\begin{array}{c}\text { Internal Heat } \\
\text { Transfer Coefficient }\end{array}$ & - & - & 0.1111 & \\
\hline \multirow{8}{*}{$\begin{array}{l}\text { dry stone } \\
\text { cladding on the } \\
\text { external wall } \\
\text { with aerogel } \\
\text { porous board }\end{array}$} & 10 & $\begin{array}{c}\text { External Heat } \\
\text { Transfer Coefficient }\end{array}$ & - & - & 0.0435 & \multirow{8}{*}{1.394} \\
\hline & 8 & Cladding & 0.020 & 0.4 & 0.0500 & \\
\hline & 4 & $\begin{array}{l}\text { Aerogel Porous } \\
\text { Board }\end{array}$ & 0.01 & 0.033 & 0.3030 & \\
\hline & & Air Layer & - & - & 0.0860 & \\
\hline & 8 & Cement Mortar & 0.015 & 1.5 & 0.0100 & \\
\hline & 4 & $\begin{array}{l}\text { Reinforced } \\
\text { Concrete }\end{array}$ & 0.150 & 1.4 & 0.1071 & \\
\hline & 8 & Cement Mortar & 0.01 & 1.5 & 0.0067 & \\
\hline & $7 \quad\{\}^{2}$ & $\begin{array}{c}\text { Internal Heat } \\
\text { Transfer Coefficient }\end{array}$ & - & - & 0.1111 & \\
\hline
\end{tabular}

\section{Case Study: The Retrofitting of a Typical Multistory Building}

In this case study, the selected residential building for retrofitting is located in downtown Kaohsiung, an area with extremely high real estate values. Therefore, the retrofit interventions have to include only the compact and easy/fast-to-install building envelope system. This building is representative of typical residential buildings in Taiwan, thereby presenting an exemplary retrofitting case study for potential wide applications in the Taiwanese context. 


\subsection{Climatic and Environmental Conditions}

Retrofitting this residential building is challenged by its climate and site conditions, which are associated with dynamic and variable weather conditions in a humid subtropical climate, with abundant local rains, sunny days and brief periods of overcast skies. The location of this building lies above the $22.4^{\circ}$ north latitude, a degree south of the Tropic of Cancer in Kaohsiung, Taiwan. This region experiences temperatures ranging from an average low of $10^{\circ} \mathrm{C}\left(50^{\circ} \mathrm{F}\right)$ in January to the average high of $33^{\circ} \mathrm{C}\left(91^{\circ} \mathrm{F}\right)$ in July, with a consistent daytime length throughout the year, approximately $13.5 \mathrm{~h}$ of daylight on the summer solstice and $10.5 \mathrm{~h}$ on the winter solstice. With more than $2210 \mathrm{~h}$ of bright sunshine, the city is one of the sunniest areas in Taiwan. The noon temperature reaches $35^{\circ} \mathrm{C}$ in the summer and $25{ }^{\circ} \mathrm{C}$ in winter. The high summer sun angles emphasize the need to provide a sheltering roof to control light levels, solar gains and temperatures in the indoor environment. Despite about 225 bright sunny days per year, there remains a monthly rhythm of overcast or rainy days, including an average of 2-3 typhoons per month during summer time. The annual mean solar irradiation and precipitation are $3896 \mathrm{MJ} / \mathrm{m}^{2}$ and $1968.2 \mathrm{~mm}$, respectively [29].

\subsection{Case Study Building}

Multistory buildings are commonly seen in urban areas of Taiwan and they are usually built alongside streets to provide spaces for multiple uses. For instance, the ground floor is usually used for retail or a restaurant, with upper floors being used as residential units or offices. This typical building typology represents $90 \%$ of Taiwanese building stock and contributes to $15.3 \%$ of energy consumption [47]. Mostly built in the 90 s, they have poor energy efficiency due to the absence of a stringent building code. Being built adjacently to other buildings in a long stretch, they also represent a great potential of widespread fire hazard. Therefore, a building of this type is selected in the case study to explore a retrofitting approach to improve its energy efficiency with improved fire safety.

As shown in Figure 8, this east facing building is a $13.45-\mathrm{m}$ tall reinforced concrete building composed of four floors. The total building area is about 347.15 square meters, and the floor-to-ceiling height of each story is $3.3 \mathrm{~m}$, with a $60 \%$ window-to-wall ratio on the glazed building façade. This large window-to-wall ratio design ensures an even distribution of natural light. However, it leads to a strong greenhouse effect throughout the day. This greenhouse effect accumulates a lot of solar heat during the summer and leads to an overheated indoor environment. Although there is a ceiling-level solar shading design on each floor, the solar heat gain via the glazing and wall still represents a significant cooling load and must be reduced.

As shown in Figure 9, this building has a rectangular floor plan with a length of $19.73 \mathrm{~m}$ and a width of $4.74 \mathrm{~m}$. The building offers spaces for both residential and commercial uses. The first floor is rented out by the owner as a shop and the second to fourth floors are for residential use. Since the building faces east and the homeowner adheres the opaque film on the glass in order to reduce the solar radiation in the morning. Thus, there was insufficient penetration of natural light, leading to poorly lit indoor space before the retrofit. The results of measuring indoor illuminance by the illuminometer indicated that at 10:00 in the morning, the illuminance near the window can reach up to 1050 Lux. The daylight can only diffuse to the indoor depth of $2 \mathrm{~m}$ in the afternoon and the average illuminance at other measurement locations is below 250 Lux. The uniformity of illuminance level on the entire floor was rather poor.

\subsection{Retrofitting Scenario: Building Envelope}

In order to reduce the heat gain of the building envelope and the electricity consumption of the air conditioning system in this case study, we reduced the window area by $35 \%$, changed the glass from clear tempered glass to green tempered glass and installed a dry cladding system on the existing external wall with the aerogel porous board. After retrofitting this building, the SHGC of the glass was reduced from 0.83 to 0.60 and the visi- 
ble light transmission of the glass was changed from 0.88 to 0.74 . Recladding significantly reduced the overall $U$ value of the wall from 3.495 to $1.394 \mathrm{~W} / \mathrm{m}^{2} / \mathrm{K}$ because of its fabric construction change.

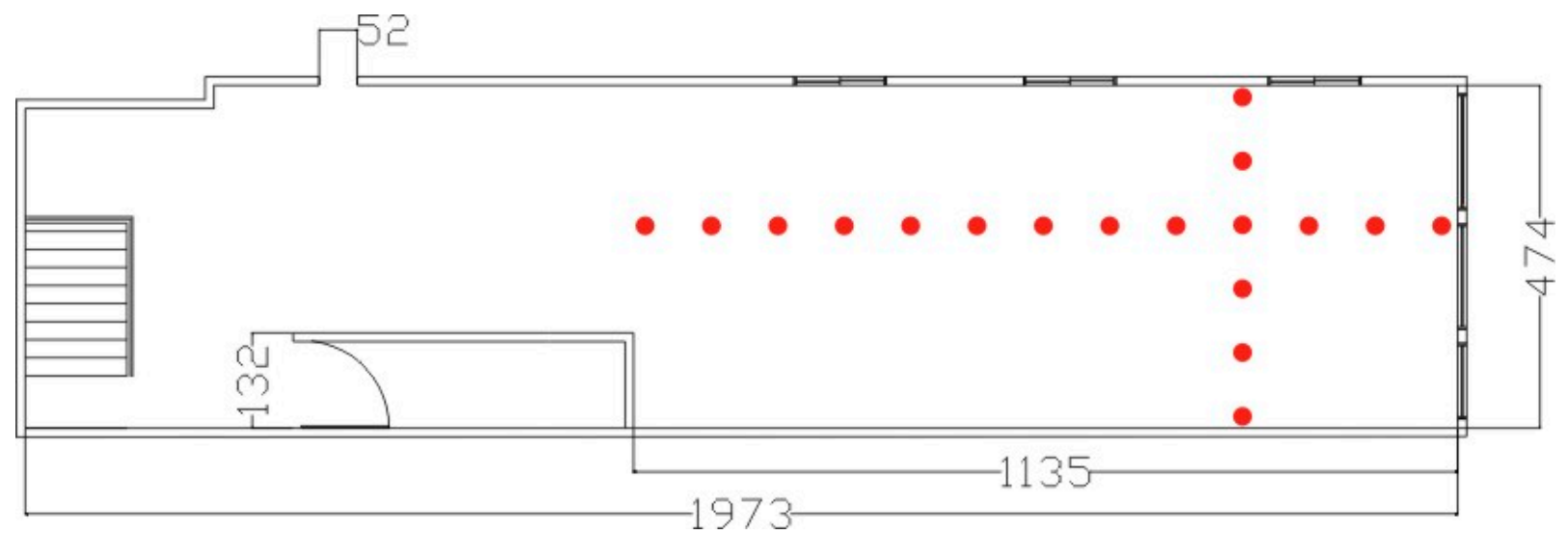

(a)

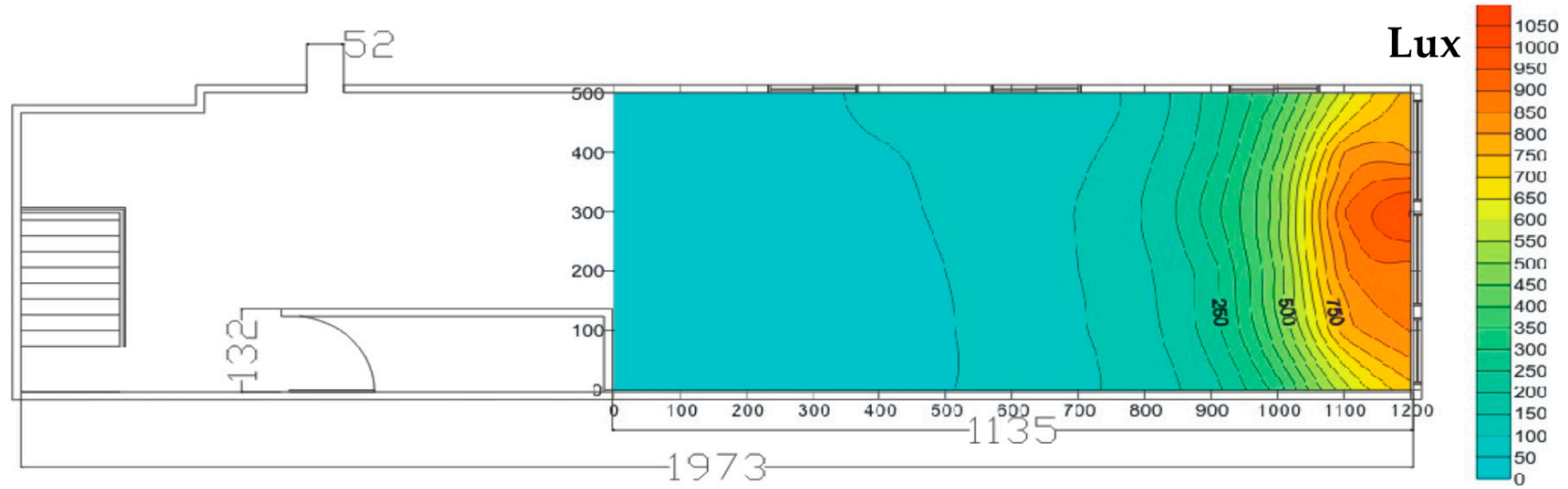

(b)

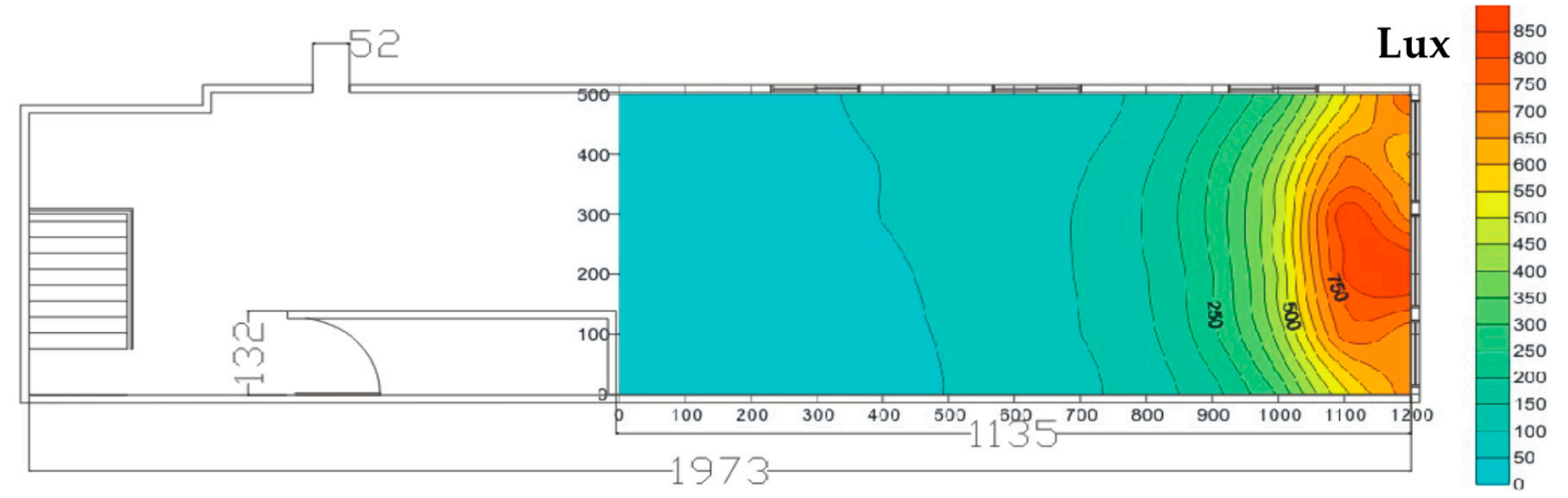

(c)

Figure 9. (a) Existing floor plan for typical floor, (b) illuminance contour at 10:00 and (c) illuminance contour at 14:00.

\subsection{Evaluation on the Energy Efficiency Improvement}

In this study, the building energy simulation and analysis platform (BESTAI) was adopted to conduct simulations of energy consumption. It is the integrated graphical interface software program developed for the purpose of conducting an EnergyPlus building energy consumption analysis as a dynamic engine. BESTAI provides users with the modeling and design of an on-line real-time building simulation analysis to obtain optimal 
energy analysis data in Taiwan. In addition, it offers users a customized analysis with various reporting functions, such as: ROI (return on investment) assessment, the annual energy consumption analysis and various types of electricity price estimates from the Taiwan Power company and other analytical services. BESTAI integrates ESCO, BEMS, the construction materials and equipment industry to provide customized recommendations for different conditions and applications through functional modules. It received a 2017 R\&D 100 Award [48].

For computer simulation and modeling, the physical parameters include the window, the external wall structure and the window-to-wall ratio. The numbers of occupants, the heat gain of appliances and lighting for each floor are listed in Table 5. In general, the lighting equipment, computer and appliances on the first floor have identical operating periods corresponding to the staff's work shifts from 7:30 am to 8:30 pm. A load of operating lighting, computers and appliances, according to the period, on the other floors, are set according to the survey by Lin et al. [47].

Table 5. Physical parameters for the building.

\begin{tabular}{|c|c|c|}
\hline Items & Before & After \\
\hline $\begin{array}{c}\text { U-value @ exterior } \\
\text { wall }\end{array}$ & $3.495 \mathrm{~W} / \mathrm{m}^{2} \mathrm{~K}$ & $1.394 \mathrm{~W} / \mathrm{m}^{2} \mathrm{~K}$ \\
\hline U-value@ roof & $1.0 \mathrm{~W} / \mathrm{m}^{2} \mathrm{~K}$ & $1.0 \mathrm{~W} / \mathrm{m}^{2} \mathrm{~K}$ \\
\hline Window to Wall Ratio & 0.9 (façade) & 0.65 (façade) \\
\hline U-value @ window & $5.5 \mathrm{~W} / \mathrm{m}^{2} \mathrm{~K}$ & $5.5 \mathrm{~W} / \mathrm{m}^{2} \mathrm{~K}$ \\
\hline Glass & $\begin{array}{c}\text { Clear glass } \\
\mathrm{U}=5.97 \mathrm{~W} / \mathrm{m}^{2} \mathrm{~K} \\
\text { SHGC }=0.83 \\
\text { Visible Light Transmittance }=0.88\end{array}$ & $\begin{array}{c}\text { Green glass } \\
\mathrm{U}=5.97 \mathrm{~W} / \mathrm{m}^{2} \mathrm{~K} \\
\text { SHGC }=0.60 \\
\text { Visible Light Transmittance }=0.73\end{array}$ \\
\hline No. of people & $\begin{array}{c}\text { 1st F: } 2 \text { staff }+20 \text { Persons } / \mathrm{h} \\
\text { 2nd-4th F: } 4 \text { Persons / each story }\end{array}$ & $\begin{array}{c}\text { 1st F: } 2 \text { staff }+20 \text { Persons } / \mathrm{h} \\
\text { 2nd-4th F: } 4 \text { Persons / each story }\end{array}$ \\
\hline Lighting & $\begin{array}{c}\text { 1st F: } 660 \mathrm{~W}\left(10 \mathrm{~W} / \mathrm{m}^{2}\right) \\
\text { 2nd-4th F: } 200 \mathrm{~W} / \text { each story }\end{array}$ & $\begin{array}{c}\text { 1st F: } 660 \mathrm{~W}\left(10 \mathrm{~W} / \mathrm{m}^{2}\right) \\
\text { 2nd-4th F: } 200 \mathrm{~W} / \text { each story }\end{array}$ \\
\hline Appliance & $\begin{array}{c}\text { 1st F: } 1200 \mathrm{~W} \\
\text { 2nd-4th F: } 500 \mathrm{~W} / \text { each story }\end{array}$ & $\begin{array}{c}\text { 1st F: } 1200 \mathrm{~W} \\
\text { 2nd-4th F: } 500 \mathrm{~W} / \text { each story }\end{array}$ \\
\hline
\end{tabular}

The installed air conditioning system at this building is a multisplit type air conditioning system. The total cooling capacity of the air conditioning system installed on the first floor was $33 \mathrm{~kW}$ and on the other feet was $6 \mathrm{~kW}$ and the specified coefficient of performance (COP) was 2.7. The start and stop of the air conditioners on the first floor were scheduled according to the different seasons. In the summertime, the shop on the first floor had a significant cooling demand from June to September, as shown in Table 6. Conversely, the cooling load was low in winter, so the operating hours of air conditioner were shortened on regular working days. On other floors, the occupants' air conditioning hours were from $8 \mathrm{pm}$ to 2 am on weekdays and from 1 pm to 2 am on Sunday and holidays.

The weather data was taken from the latest typical meteorological years (TMY3) for the building energy simulation of Taiwan proffered by the Architecture and Building Research Institute (ABRI) [49]. Basically, it sampled 15 standard years from 1998 to 2012 as standard weather data. The weather data can be generated to analyze the power consumption of an air conditioning system once the user selects the location of the building. 
Table 6. Monthly operation schedule for switching on-and-off air conditioner.

\begin{tabular}{cc}
\hline Month & Periods (hh:mm) \\
\hline January & Rate of Operating Load (\%) \\
\hline February & $10: 00-18: 00$ \\
\hline March & $10: 00-19: 00$ \\
\hline April & $09: 00-19: 00$ \\
\hline May & $09: 00-20: 00$ \\
\hline June & $08: 00-20: 00$ \\
\hline July & $08: 00-20: 00$ \\
\hline August & $08: 00-20: 00$ \\
\hline September & $08: 00-20: 00$ \\
\hline October & $09: 00-20: 00$ \\
\hline November & $10: 00-19: 00$ \\
\hline December & $10: 00-19: 00$ \\
\hline
\end{tabular}

Figure 10 shows the breakdown of electricity consumption by equipment type in this building. Before the renovation, about $41 \%$ electricity consumption was associated with the air conditioning system. Lighting system and appliance accounted for $26.5 \%$ and $32.0 \%$ of the total electricity consumption, respectively. With our proposed renovation concept the total and air conditioning system's electricity consumption shown in Figure 11 would be reduced by $29 \%$ and $70 \%$, respectively, resulting in the air conditioning system accounting for $16.69 \%$ of the total electricity consumption. Figure 12 shows the comparison between the simulations and the real monthly electricity consumption of this building. The monthly simulation result gave a power consumption that was significantly higher than real electricity consumption in the first half of the year. The simulated results came out with $9.5 \%$ and $4.0 \%$ more electricity consumption than the metered data before and after renovation. This discrepancy could have occurred because the weather data file used in BESTAI was for the years between 1998 and 2012, while the actual data gathered in this building was for the years 2019-2020. This case study result implies that the proper use of the aerogel porous board in buildings not only reduces the energy usage but also downsizes the HVAC system during the design.

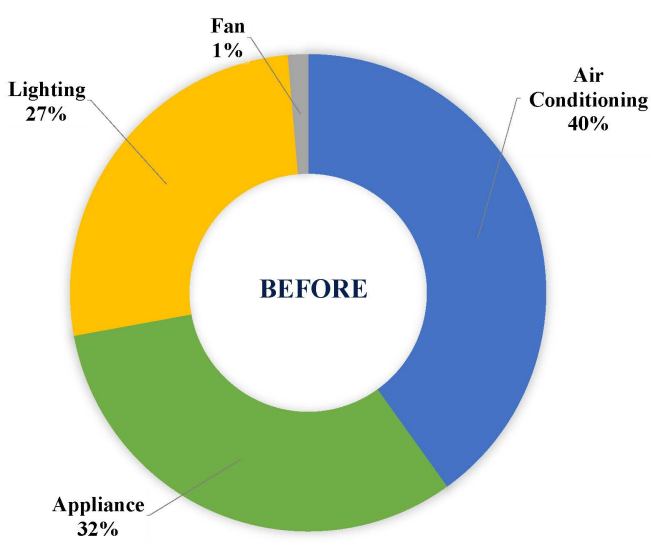

(a)

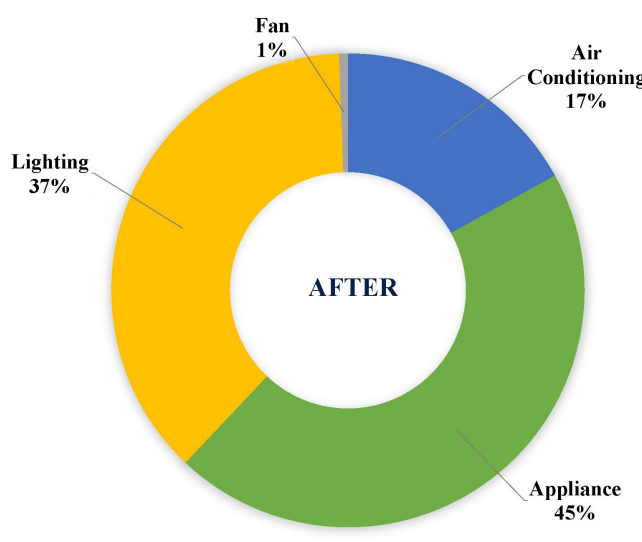

(b)

Figure 10. Comparison of annual electricity use breakdown for a residential building case study before (a) and after (b) renovation. 


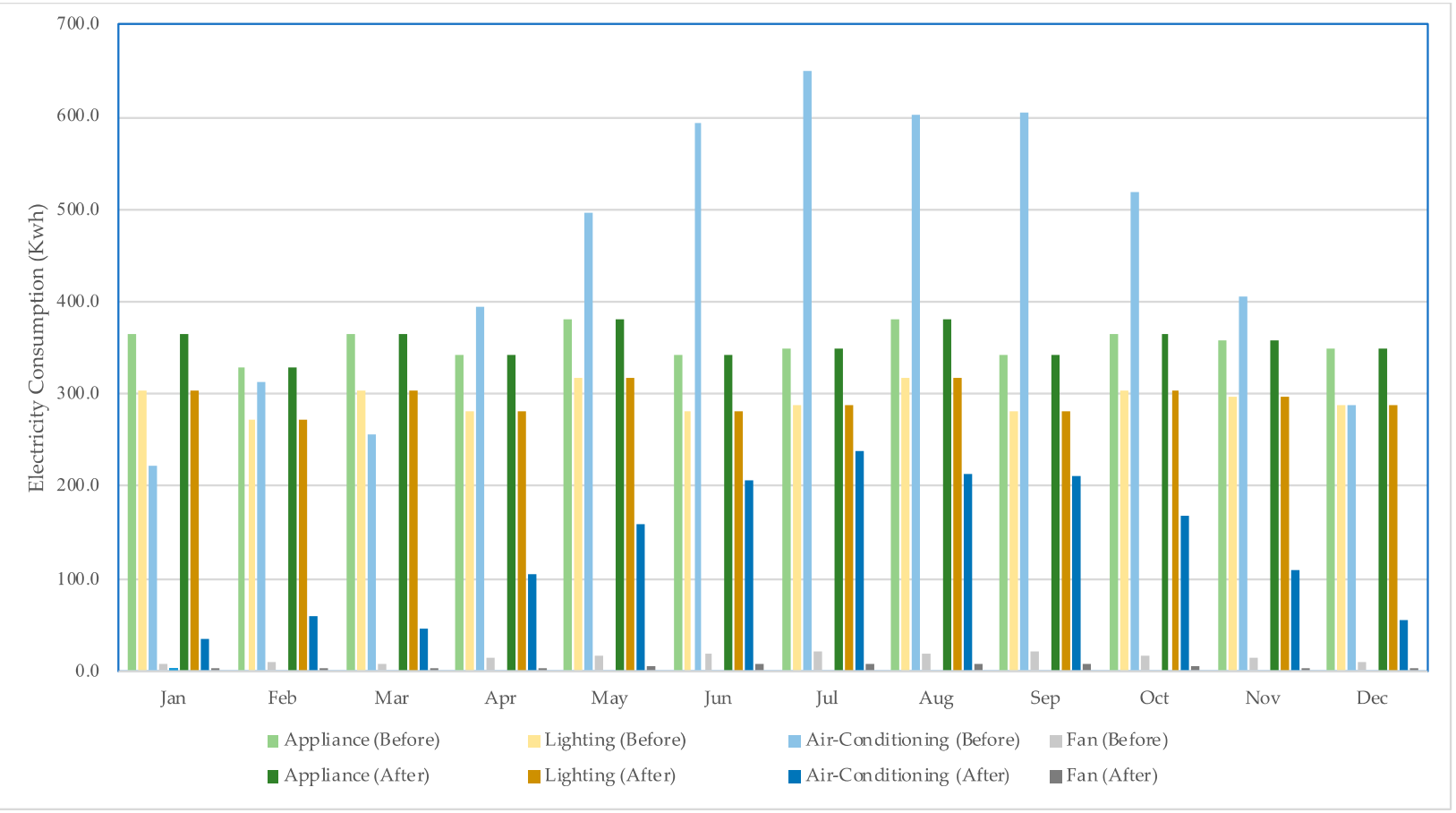

Figure 11. Electricity consumptions for the proposed retrofitting scenario.

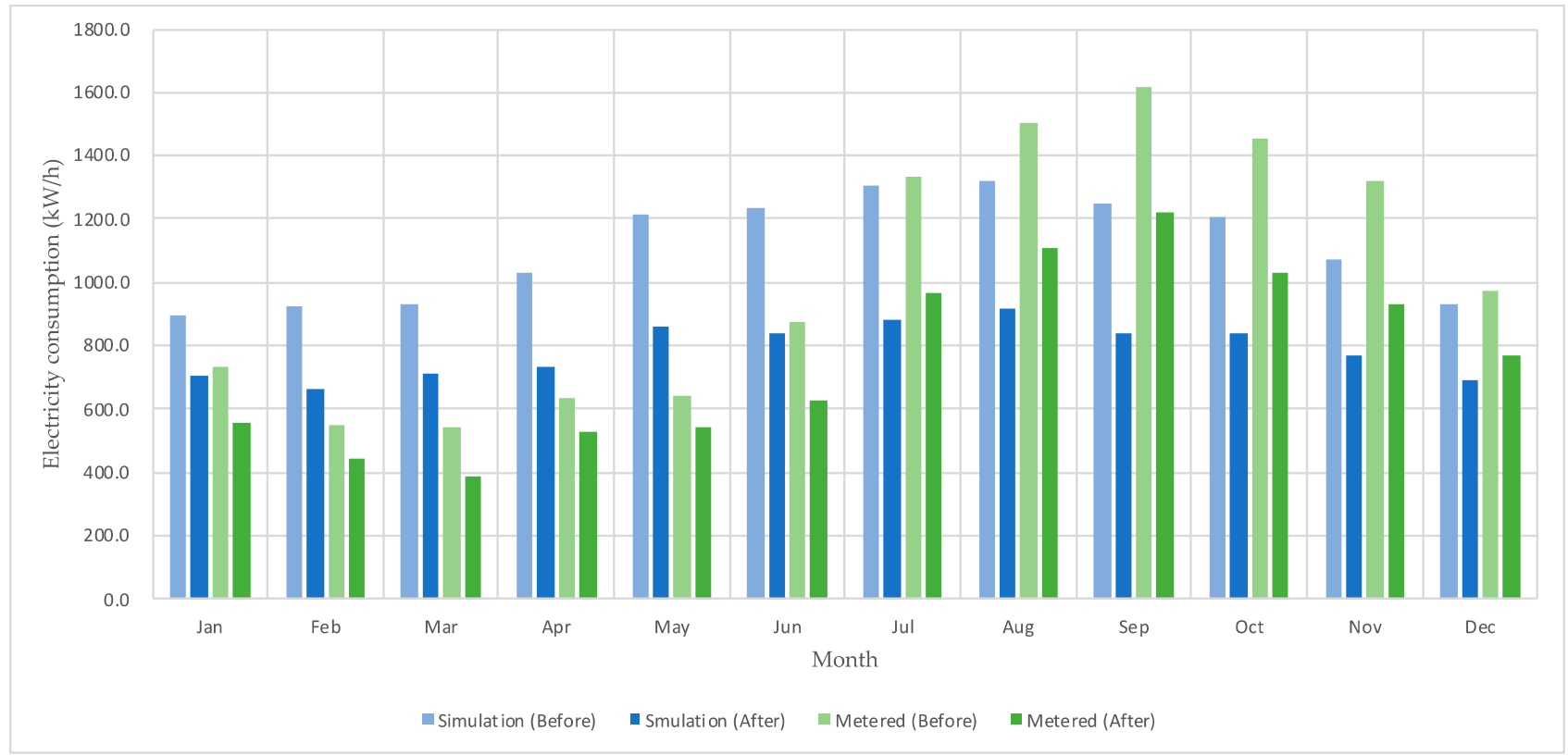

Figure 12. Comparing the monthly electricity consumption between simulation and metered.

\section{Conclusions}

In the study, a new aerogel porous board for application in Taiwan was investigated. It can be used in the near future for reducing energy consumption and enhancing fire safety performance in buildings due to its low thermal conductivity and good fire resistance. The results of the experiment are summarized as follows:

(1) A well-designed method including emulsification condensation gelation and controlled ambient drying at $150{ }^{\circ} \mathrm{C}$ for $24 \mathrm{~h}$ was developed to fabricate an aerogel porous board with a uniform skeleton. One of advantages is that it was fabricated under am- 
bient pressure drying without tedious surface modification and the solvent exchange process. The reproducibility of the aerogel porous board was also good, especially with respect to mesopore size distributions. This suggests a low fabrication cost is technically viable.

(2) For the microstructural properties, it was possible to verify high values of porosity, low density and superhydrophobicity for the aerogel porous board, similar to that of the benchmarked aerogel particle.

(3) For the thermal insulation property, adding $1 \mathrm{wt} \%$ of glass fiber to the aerogel porous board could increase its mechanical strength but lead to the thermal conductivity of the aerogel porous board being higher than that of the commercially available aerogel particle. Compared with the other typical foam boards, the thermal conductivity of the aerogel porous board was slightly higher than that of other ones, but the $U$ values of the EWI system with the aerogel porous board should be similar to that with other foam boards.

(4) For the fire resistance property, the PU and PS foam boards were flammable, even when the flame-retardants were added to these foam boards. Therefore, reducing the flammability of traditional EWI materials by using the flame retardant is hard to achieve. The proposed aerogel porous board can dramatically inhibit the combustion intensity and restrict the heat release during combustion without using additives. It could reach non-flammable class 1 in accordance with CNS 14705-1-2013.

(5) Concerning the hygric performance, the water absorption of the aerogel porous board was low $\left(0.186 \mathrm{~g} / 100 \mathrm{~cm}^{2}\right)$ and the surface was hydrophobic, so it is suitable to use under the typical Taiwan climate, i.e., high temperature and humidity climate. The aerogel porous board will not absorb too much water vapor and cause a decrease in thermal insulation performance.

(6) From the energetic point of view, the pilot study in this paper suggests that the aerogel porous board could be applied feasibly in regions with hot and humid climates in general and particularly in Taiwan. The evaluation result of the case study reported in this paper indicated that the utilization of dry construction with stone cladding on the external wall with an additional aerogel porous board unit could reduce $26.1 \%$ electricity consumption of a four-story building.

Author Contributions: Conceptualization, S.-K.L. and X.-F.Z.; Methodology, K.-S.L. and S.-K.L.; Data curation, formal analysis, investigation and validation, K.-S.L. and C.-H.H.; Supervision, S.-K.L.; Writing-Original draft, S.-K.L.; Writing-Review and editing, S.-K.L. and X.-F.Z. All authors have read and agreed to the published version of the manuscript.

Funding: This research was funded by Ministry of Science and Technology, Taiwan, grant number 109-2221-E-214-002, and Bureau of Energy, Ministry of Economic Affairs, Taiwan, grant number 110-E0209. The APC was partially funded by IOAP, University of Nottingham (UK).

Institutional Review Board Statement: Not applicable.

Informed Consent Statement: Not applicable.

Data Availability Statement: The data that support the findings of this study are available from the corresponding author, upon reasonable request.

Acknowledgments: The authors wish to express their sincere appreciation for the support and project funding provided by the Ministry of Science and Technology, in Taiwan (109-2221-E-214-002) and Bureau of Energy, Ministry of Economic Affairs under the contracts of 110-E0209, so that the project could be carried out smoothly.

Conflicts of Interest: The authors declare no conflict of interest.

\section{References}

1. Building and Climate Change: Summary for Decision-Makers. 2009. Available online: https://wedocs.unep.org/bitstream/ handle/20.500.11822/32152/BCC_SDM.pdf?sequence=1\&isAllowed=y (accessed on 31 May 2021).

2. Lombard, L.; Ortiz, J.; Pout, C. A review on buildings energy consumption information. Energy Build. 2008, 40, 394-398. [CrossRef] 
3. Transition to Sustainable Buildings-Strategies and Opportunities to 2050. Available online: https://www.oecd.org/publications / transition-to-sustainable-buildings-9789264202955-en.htm (accessed on 31 May 2021).

4. Kisilewicz, T.; Cisak, M.F.; Barkanyi, T. Active thermal insulation as an element limiting heat loss through external walls. Energy Build. 2019, 109541. [CrossRef]

5. Pedroso, M.; Flores-Colen, I.; Silvestre, J.D.; Gomes, M.G.; Silva, L.; Sequeira, P.; De Brito, J. Characterisation of a multilayer external wall thermal insulation system. Application in a Mediterranean climate. J. Build. Eng. 2020, 101265. [CrossRef]

6. Long, L.S.; Ye, H. The roles of thermal insulation and heat storage in the energy performance of the wall materials: A simulation study. Sci. Rep. 2016, 6, 24181. [CrossRef] [PubMed]

7. Maia, J.; Ramos, N.; Veiga, R. Evaluation of the hygrothermal properties of thermal rendering systems. Build. Environ. 2018, 144, 437-449. [CrossRef]

8. $\quad$ Ramos, N.; Maia, J.; Souza, A.R.; Almeida, R.M.S.F.; Silva, L. Impact of incorporating NIR reflective pigments in finishing coatings of ETICS. Infrastructures 2021, 6, 79. [CrossRef]

9. Pisello, A.L.; Fortunatic, E.; Fabianib, C.; Mattiolic, S.; Dominicic, F.; Torrec, L.; Cabezad, L.F.; Cotana, F. PCM for improving polyurethane-based cool roof memebranes durability. Sol. Energy Mater. Sol. Cells 2017, 160, 34-42. [CrossRef]

10. Koob, S.F.; Grace, R.; Mannix, L. 'Same as Grenfell Tower': Cladding fears as fire rips through Melbourne CBD apartment building. The Age, 4 February 2019.

11. Lucas, C. Docklands owners sue for \$24m over fire, as date to fix cladding looms. The Age, 10 September 2018.

12. Horgan, R. Fire breaks out at London tower block wrapped in Grenfell-style cladding. New Civil Engineer, 7 May 2021.

13. Approved Document B: Fire Safety, Volume 2 Buildings Other Than Dwellinghouses, 2013th ed.; Department of Communities and Local Government: London, UK, 2013.

14. DIN 4102-1. Fire Behaviour of Building Materials and Elements—Classification of Building Materials-Requirements and Testing; German Institute for Standardization: Berlin, Germany, 1998.

15. European Organization for Technical Approvals (EOTA). Guideline for European Technical Approval of External Thermal Insulation Composite Systems with Rendering; ETAG 004; EOTA: Brussels, Belgium, March 2013.

16. Pisello, A.L. State of the art on the development of cool coatings for buildings and cities. Sol. Energy 2017, 144, 660-680. [CrossRef]

17. Bourbigot, S.; Duquesne, S. Fire retardant polymers: Recent developments and opportunities. J. Mater. Chem. 2007, 17, 2283-2300. [CrossRef]

18. Chattopadhyay, D.K.; Webster, D.C. Thermal stability and flame retardancy of polyurethanes. Prog. Polym. Sci. 2009, 34, 1068-1133. [CrossRef]

19. Liu, J.R.; Yan, L.; Zhang, Q.; Sang, X. Preparation and properties of polyurethane foams flame retarded by DAMDOPO/ammonium polyphosphate. J. Funct. Mater. 2017, 48, 1236-1243.

20. Duquesne, S.; Le-Bras, M.; Bourbigot, S.; Delobel, R.; Vezin, H.; Camino, G.; Eling, B.; Lindsay, C.; Roels, T. Expandable graphite: A fire retardant additive for polyurethane coatings. Fire Mater. 2003, 27, 103-117. [CrossRef]

21. Riffat, S.B.; Qiu, G. A review of state-of-the-art aerogel applications in buildings. Int. J. Low-Carbon Technol. 2013, 8, 1-6. [CrossRef]

22. Lamy-Mendes, A.; Pontinha, A.D.R.; Alves, P.; Santos, P.; Durães, L. Progress in silica aerogel-containing materials for buildings' thermal insulation. Constr. Build. Mater. 2021, 286, 122815. [CrossRef]

23. Kistler, S.S. Coherent Expanded Aerogels and Jellies. Nature 1931, 127, 741. [CrossRef]

24. Fantucci, S.; Fenoglio, E.; Grosso, G.; Serra, V.; Perino, M.; Marino, V.; Dutto, M. Development of an aerogel-based thermal coating for the energy retrofit and the prevention of condensation risk in existing buildings. Sci. Technol. Built Environ. 2019, 25, 1-10. [CrossRef]

25. Golder, S.; Narayanan, R.; Hossain, M.R.; Islam, M.R. Experimental and CFD Investigation on the Application for Aerogel Insulation in Buildings. Energies 2021, 14, 3310. [CrossRef]

26. Buratti, C.; Moretti, E.; Zinzi, M. High Energy-Efficient Windows with Silica Aerogel for Building Refurbishment: Experimental Characterization and Preliminary Simulations in Different Climate Conditions. Buildings 2017, 7, 8. [CrossRef]

27. Kumar, A.S.; Deepankar, A.K.; Zymantas, R. Aerogel based thermal insulating cementitious composites: A review. Energy Build. 2021, 245, 111058.

28. Pedroso, M.; Flores-Colen, I.; Silvestre, J.D.; Gomes, M.G.; Silva, L.; Ilharcoc, L. Physical, mechanical, and microstructural characterisation of an innovative thermal insulating render incorporating silica aerogel. Energy Build. 2020, $211,109793$. [CrossRef]

29. Central Weather Bureau. Available online: https://www.cwb.gov.tw/eng/ (accessed on 1 July 2021).

30. Statute for Expediting Reconstruction of Urban Unsafe and Old Buildings. Available online: https://law.moj.gov.tw/ENG/ LawClass /LawAll.aspx?pcode=D0070249 (accessed on 1 July 2021).

31. Webb, A.L. Energy retrofits in historic and traditional buildings: A review of problems and methods. Renew. Sustain. Energy Rev. 2017, 77, 748-759. [CrossRef]

32. Ruggeri, A.G.; Gabrielli, L.; Scarpa, M. Energy Retrofit in European Building Portfolios: A Review of Five Key Aspects. Sustainability 2020, 12, 7465. [CrossRef]

33. Corrêa, D.; Flores-Colen, I.; Silvestre, J.D.; Pedroso, M.; Santos, R.A. Old Buildings' Façades: Fieldwork and Discussion of Thermal Retrofitting Strategies in a Mediterranean Climate. Designs 2020, 4, 45. [CrossRef] 
34. Friess, W.A.; Rakhshan, K. A review of passive envelope measures for improved building energy efficiency in the UAE. Renew. Sustain. Energy Rev. 2017, 72, 485-496. [CrossRef]

35. Guedes, M.C.; Cantuaria, G. Bioclimatic Architecture in Warm Climates: A Guide for Best Practices in Africa; Springer Nature: Gewerbestrasse, Switzerland, 2019.

36. Cozza, E.S.; Alloisio, M.; Comite, A.; Di Tanna, G.; Vicini, S. NIR-reflecting properties of new paints for energy-efficiency buildings. Sol. Energy 2015, 116, 108-116. [CrossRef]

37. Long Long Clean Room Technology Co. Ltd. Available online: https:/ /www.longlongsystem.com/en/ (accessed on 1 July 2021).

38. LAI ADVANCE INDUSTRY Co. Ltd. Available online: http://www.laiadvance.com.tw/en_index.php (accessed on 1 July 2021).

39. Lee, H.K.; Tsai, P.C.; Yu, H.Y.; Wu, D.W. Aerogel Particles and Method of Making the Same. U.S. Patent No. 10,781,289 B2, 22 September 2020.

40. ASTM D7984-16. Standard Test Method for Measurement of Thermal Effusivity of Fabrics Using a Modified Transient Plane Source (MTPS) Instrument; ASTM International: West Conshohocken, PA, USA, 2016.

41. BSMI (Bureau of Standards). CNS 14705-1: 2013, Method of Test for Heat Release Rate for Building Materials-Part 1: CONE Calorimeter Method; Bureau of Standards, Metrology \& Inspection, M.O.E.A.: Taipei, Taiwan, 2013.

42. ASTM D570-98. Standard Test Method for Water Absorption of Plastics; ASTM International: West Conshohocken, PA, USA, 2018.

43. Rouquerol, J.; Avnir, D.; Fairbridge, C.W.; Everett, D.H.; Haynes, J.M.; Pernicone, N.; Ramsay, J.D.F.; Sing, K.S.W.; Unger, K.K. Recommendations for the Characterization of Porous Solids. Pure Appl. Chem. 1994, 66, 1739-1758. [CrossRef]

44. Wei, T.Y.; Chang, T.F.; Lu, S.Y.; Chang, Y.C. Preparation of monolithic silica aerogel of low thermal conductivity by ambient pressure drying. J. Am. Ceram. Soc. 2007, 90, 2003-2007. [CrossRef]

45. Morgan, A.B.; Wilkie, C.A. Flame Retardant Polymer Nanocomposites; John Wiley \& Sons, Inc.: Hoboken, NJ, USA, 2007.

46. ISO 10292 1994. Glass in Building-Calculation of Steady-State U Values (Thermal Transmittance) of Multiple Glazing; The International Organization for Standardization: Geneva, Switzerland, 1994.

47. Lin, S.C.; Lin, A. The Residential Sector Electricity Use Research in Taiwan. J. Taiwan Energy 2017, 4, $285-302$.

48. Building Energy Simulation Technology with Artificial Intelligence (BESTAI). Available online: https://www.itri.org.tw/ english/Building-Energy-Simulation-Technology-with-Artificial-Intelligence-(BESTAI)?CRWP=1001707753263403122 (accessed on 31 May 2021).

49. The Development and Research on Hourly Typical Meteorological Years (TMY3) for Building Energy Simulation Analysis of Taiwan. Available online: https: / /www.abri.gov.tw/en/News_Content.aspx?n=908\&s=40723 (accessed on 31 May 2021). 